\title{
Prevalence and Risk Factors for Hypertension in Adults Living in Central Development Region of Nepal
}

\author{
Chataut J, Adhikari RK, Sinha NP
}

Department of Community Medicine,

Kathmandu University School of Medical Sciences,

Dhulikhel Hospital, Kavre, Nepal

Corresponding Author

Dr. Jagdish Chataut

Department of Community Medicine

Kathmandu University School of Medical Sciences

Dhulikhel Hospital, Kavre, Nepal.

E-mail: jagdish_chataut@yahoo.com

Citation

Chataut J, Adhikari RK, Sinha NP. The Prevalence of and Risk Factors for Hypertension in Adults Living in Central Development Region of Nepal. Kathmandu Univ Med J 2011;33(1)13-8.

\begin{abstract}
Background

Hypertension is the commonest cardiovascular disorder and now regarded as major public health problem. It is a precursor to major diseases like myocardial infarction, stroke, renal failure etc. There are very limited community based data on hypertension in Nepal, so, information on the prevalence of hypertension in the population is desirable.
\end{abstract}

\section{Objectives}

To estimate the prevalence of hypertension and to explore the risk factors associated with hypertension.

\section{Methods}

In a cross sectional study, a total of 527 subjects (males $n=214$ and females $\mathrm{n}=313$ ) participated in our study (age $\geq 18$ years). The participants underwent anthropometric measurement and blood pressure and answered a pretested questionnaire. Hypertension was defined as per JNC VII criteria.

\section{Results}

Overall prevalence of hypertension was $22.4 \%$ (males: $32.7 \%$ and female: $15.3 \%$ ). Age specific prevalence of hypertension showed significant progressive increase in blood pressure ranging from $8 \%$ to $35 \%$. Almost $40 \%$ of hypertensives did not know about their status. Bivariate analysis showed significant relationship of hypertension with gender, age, literacy, physical inactivity, body mass index (BMI), smoking and alcohol consumption. Multivariate analysis excluded literacy but all other risk factors continued to show positive association with hypertension.

\section{Conclusion}

Being elderly, less physical activity, obese/overweight, smoking and alcohol consumption are significant risk factors of hypertension. Therefore, intervention measures are warranted emphasizing on modifiable risk factors such as smoking, alcohol consumption, physical activity and obesity to prevent hypertension.

\section{KEY WORDS}

cross-sectional study, hypertension, JNC VII criteria, prevalence, risk factors

\section{INTRODUCTION}

Hypertension is the commonest cardiovascular disorder and now regarded as major public health problem. ${ }^{1}$ It is a precursor to major diseases like myocardial infarction, stroke, renal failure etc. Overall $26.4 \%$ (972 million) of the adult world population was estimated to have hypertension in the year 2000, a figure that is projected to increase to $29.2 \%$ ( 1.56 billion) by the year $2025 .^{2}$

An epidemiological shift in the prevalence of hypertension in developing countries as compared to developed countries has been observed. ${ }^{3,4}$
Accurate and reliable information about prevalence of hypertension and its risk factors is a prerequisite for designing strategies for its effective control and prevention. There are however very limited community based data on hypertension in Nepal. Hence the present study has been undertaken which will not only measure the prevalence of hypertension in the men and women living in study area, but will also determine the factors responsible with reference to medical, social and individual characteristics. 


\section{METHODS}

All the procedures were done according to a study protocol approved by the Institutional Review Committee, Kathmandu University School of Medical Sciences. The present community based cross-sectional study was conducted on 527 subjects aged 18 years and above of Bolde, a rural village in hilly region of central part of the country which has got the population of 3255 . The sample size was calculated with the formula $4 p q / d^{2}$. Where $(p)$ is taken $10 \%$ and (d) $5 \%$ of $p$, the required sample size was calculated as 900 . Ultimately sample size was obtained by taking the proportion of 18 years and above from the above mentioned value.

The purpose of visit was explained to the family members and their co-operation sought. The verbal consent was obtained from every participant. People who did not give their verbal consent or who were not resident of the village, but visiting were excluded from the study.

The predominant religion of the study population was Buddhist and Hindus and the chief occupation was farming. Majority of the population consumed non-vegetarian diet. For the health services they rely on government sub health post and Dhulikhel hospital outreach center. The study was conducted by making house to house visits, interviewing and examining all the eligible individuals in the family with pre-tested detailed questionnaire which included information on demographic characteristics (e.g. age, sex, marital status, religion, caste, education, occupation, socio economic status), diet, personal and family medical history, information on lifestyle habits such as smoking, alcohol consumption, physical activity, use of "top-added" salt to meals.

Height was measured without shoes, to the nearest $0.5 \mathrm{~cm}$ with participant standing erect against the wall with heels together and touching the wall, and head held in upright position. Weight was measured with minimum cloths and no footwear on a standardized weighing machine marked from 0 to $130 \mathrm{~kg}$ and was recorded to the nearest $0.5 \mathrm{~kg}$. Body mass index (BMI) was calculated using the formula weight in kilograms divided by the square of the height in meters weight $(\mathrm{kg}) /$ height $\left(\mathrm{m}^{2}\right)$. The criteria of diagnosis and method of blood pressure measurement for each participant were followed as per JNC VII recommendation. ${ }^{5}$ Auscultatory method with a standardized calibrated mercury column type sphygmomanometer (regularly inspected and validated) was used. Two separate measurements were obtained on the left arm of the seated subject using a cuff of an appropriate size and the average BP reading was recorded. Systolic blood pressure (SBP) is the point at which the first of two or more Korotkoff sounds is heard (onset of phase 1), and the disappearance of Korotkoff sound (onset of phase 5 ) is used to define diastolic blood pressure (DBP). The average of the readings of SBP and DBP was taken as the BP of the participant. Both the blood pressure measurements were obtained after the subject had rested for at least five minutes in a seated position. It was made sure that the subjects had not consumed any hot beverages, such as tea or coffee or smoked/ chewed tobacco or undertaken vigorous physical activity within the 30 min preceding the interview. If they had, then the measurements were postponed by 30 min.Obesity was defined as BMI > 25 for males as well as females. Based on the physical activity individuals were divided into 3 groups: sedentary, mild-to moderate and heavy physical activity. For example, desk work at the office was classified as sedentary, maintenance of a garden at home, cooking, etc were classified as mild-to-moderate physical activity, and labor intensive work, such as quarry work, construction jobs, etc., was classified as heavy physical activity. Smokers were defined as those who smoked cigarettes or bidis regularly or ex-smokers whereas non smokers were those who never smoked. Alcohol intake was categorized as nil or yes.

The data collected was tabulated and analyzed by using the SPSS (Statistical Package for Social Sciences) version 11.5 for windows. Findings were described in terms of proportions and their 95\%confidence intervals. Univariate analysis was carried out separately for each factor. Chi- square test was carried out to test the differences between proportions. The probability level of less than 0.05 was considered as significant.

\section{RESULTS}

\section{Characteristics of study sample}

The demographic characteristics of the participants are summarized in Table 1 . Out of 527 participants, $60 \%$ were women. The majority of the study samples fall under the 18 - 29 age group followed by $\geq 60$. More than half the study population was illiterate (61\%) and only $15 \%$ reported having had 10 years of school education. More than half the study population (56\%) consisted of Tamangs. Of the total population, $41 \%$ consumed alcohol and $40 \%$ were smokers. Only $8 \%$ reported to lead a sedentary life style.

The overall prevalence of hypertension in this study was $22.4 \%$. Out of the total 527 subject there were 118 subjects with hypertension (70 males and 48 females) as shown in table 2.

Distribution of hypertension according to its various stages is shown in table 3. The number of pre-hypertensive subjects is more than double the hypertensive in our study. Overall $29.6 \%$ of the study population had normal blood pressure. Knowledge of study population regarding high blood pressure is shown in table 4 . About $40 \%$ of the people who are reported to have hypertension did not know about their status and in the total study population $31 \%$ did not know about the condition called high blood pressure.

Table 5 shows prevalence of hypertension and its relation with various risk factors. Bivariate analysis reveals the progressive increase in prevalence of hypertension with 
age. It also shows the positive association of hypertension with sex, physical inactivity, literacy, BMI, smoking and consumption of alcohol whereas diet was not associated with hypertension.

Multivariate analysis showed that sex, BMI, physical inactivity, smoking and alcohol continue to be independent risk factors for hypertension as displayed in table 6.

Table 1. Demographic characteristics of study population

$\begin{array}{lrr}\text { VARIABLE } & \text { NUMBER }(\%) \\ \begin{array}{l}\text { GENDER } \\ \text { Male }\end{array} & 214 & (40.6) \\ \text { Female } & 313 & (59.4) \\ & & \\ \text { AGE GROUP } & & \\ 18-29 & 142 & (27.0) \\ 30-39 & 75 & (14.2) \\ 40-49 & 86 & (16.3) \\ 50-59 & 97 & (18.4) \\ \geq 60 & 127 & (24.1)\end{array}$

$\begin{array}{lll}\text { ETHNICITY } & 71 & (13.5) \\ \text { Brahmin } & 16 & (3.0) \\ \text { Chhetri } & 300 & (56.9) \\ \text { Tamang } & 23 & (4.4) \\ \text { Dalits } & 117(22.2)\end{array}$

$\begin{array}{lll}\text { LITERACY } & 26 & (4.9) \\ \text { Graduate } & 51 & (9.7) \\ 10+2 & 82 & (15.6) \\ \text { High School } & 42(8.0) \\ \text { Primary } & 326(61.9) \\ \text { Illiterate } & & \end{array}$

BMI

$\begin{array}{lll}\text { Normal } & 361 & (68.5) \\ \text { Underweight } & 45 & (8.5)\end{array}$

Overweight $\quad 121(23.0)$

$\begin{array}{ll}\text { Lifestyle } & \\ \text { Smoking } & 212(40.2) \\ \text { Alcohol } & 216(40.9) \\ \text { Added salt } & 128(24.3)\end{array}$

PHYSICAL ACTIVITY

$\begin{array}{lll}\text { Heavy } & 212 & (40.2) \\ \text { Moderate } & 273 & (51.8) \\ \text { Sedentary } & 42 & (8.0)\end{array}$

Table 2. Prevalence of hypertension

\begin{tabular}{lccc|}
$\begin{array}{l}\text { Sex } \\
(\%)\end{array}$ & Total Number & Hypertensive & Prevalence \\
\hline Male & 214 & 70 & \\
Female & 313 & 48 & 32.7 \\
Total & 527 & 118 & 15.3 \\
\hline
\end{tabular}

Table 3. Distribution of hypertension as per JNC VII criteria

\begin{tabular}{lcc}
\hline Classification & Number & $\%$ \\
Normal & 156 & 29.6 \\
Pre-hypertension & 253 & 48.0 \\
Hypertension Stage I & 95 & 18.0 \\
Hypertension Stage II & 23 & 4.4 \\
Total & 527 & 100
\end{tabular}

Table 4. Awareness of hypertension

$\begin{array}{lccc}\text { Status } & \text { Number (\%) } & \text { Heard of hypertension } & \text { Number (\%) } \\ \text { Aware } & 71(60.2) & \text { Yes } & 363(68.9) \\ \text { Unaware } & 47(39.8) & \text { No } & 164(31.1) \\ \text { Total } & 118(100) & \text { Total } & 527(100)\end{array}$

\section{DISCUSSION}

\section{Prevalence of hypertension}

Hypertension is the commonest cardiovascular disorder and now regarded as major public health problem. ${ }^{1} \mathrm{High}$ blood pressure is estimated to cause 7.1 million deaths annually accounting for $13 \%$ of all deaths globally. ${ }^{6}$ It is being recognized that high blood pressure is an important public health problem in developing countries. ${ }^{7}$ There are very few studies to identify the prevalence of hypertension in Nepal and still fewer are the studies done in rural areas. In the current community based cross sectional survey on 527 subjects 18 years and above of age, the prevalence of hypertension was found to be $22.4 \%$ which is much higher compared to other surveys carried out in Nepal and other parts of the world. ${ }^{8,9}$ The prevalence of hypertension has increased by 30 times among the urban population over the period of 55 years and about 10 times among rural population over a period of 36 years. ${ }^{10}$ Prevalence of hypertension in the current study $(22.4 \%)$ is much higher to that in rural areas of India (10\%) and other several studies carried out in rural India. ${ }^{10-11}$ Prevalence of the current study $(22.4 \%)$ is much higher compared to other studies on rural population rather findings are much close to the studies done on urban population. Sharma D et.al found prevalence of $19.7 \%$ in the sub urban area of Kathmandu, Rawat B et.al found prevalence to be $40 \%$ in urban population of Dharan, Vaidya $A$ et.al found $22.7 \%$ in urban population of Dharan. ${ }^{12-14}$ However differential rates are due to different cut off marks in determining the level of hypertension and also differing age groups constituting the study population. This difference in cut off marks or definition is likely to be a major factor contributing to the discordance between some of the findings of the present study and these earlier studies. 
Table 5. Bivariate relationship between risk factors and hypertension

\begin{tabular}{|c|c|c|c|c|c|}
\hline Variable & Category & Number (\%) & HTN (\%) & $x 2$ & $p$-value \\
\hline SEX & $\begin{array}{l}\text { Male } \\
\text { Female }\end{array}$ & $\begin{array}{l}214(40.6) \\
313(59.4)\end{array}$ & $\begin{array}{ll}70 & (32.7) \\
48 & (15.3)\end{array}$ & 22.08 & 0.00 \\
\hline AGE GROUP & $\begin{array}{l}18-29 \\
30-39 \\
40-49 \\
50-59 \\
\geq 60\end{array}$ & $\begin{aligned} 142 & (27.0) \\
75 & (14.2) \\
86 & (16.3) \\
97 & (18.4) \\
127 & (24.1)\end{aligned}$ & $\begin{aligned} 8 & (5.6) \\
11 & (14.7) \\
24 & (27.9) \\
34 & (35.1) \\
41 & (32.3)\end{aligned}$ & 43.126 & 0.000 \\
\hline LITERACY & $\begin{array}{l}\text { Graduate } \\
10+2 \\
\text { High School } \\
\text { Primary } \\
\text { Illiterate }\end{array}$ & $\begin{array}{ll}26 & (4.9) \\
51 & (9.7) \\
82 & (15.6) \\
42 & (8.0) \\
326 & (61.9)\end{array}$ & $\begin{aligned} 1 & (3.8) \\
5 & (9.8) \\
19 & (23.2) \\
15 & (35.7) \\
78 & (23.9)\end{aligned}$ & 14.17 & 0.007 \\
\hline $\begin{array}{l}\text { PHYSICAL } \\
\text { ACTIVITY }\end{array}$ & $\begin{array}{l}\text { Heavy Moderate } \\
\text { Sedentary }\end{array}$ & $\begin{aligned} 212 & (40.2) \\
273 & (51.8) \\
42 & (8.0)\end{aligned}$ & $\begin{array}{ll}29 & (13.7) \\
76 & (27.8) \\
13 & (30.9)\end{array}$ & 15.69 & 0.000 \\
\hline BMI & $\begin{array}{l}\text { Normal } \\
\text { Underweight } \\
\text { Overweight }\end{array}$ & $\begin{array}{l}361(68.5) \\
45(8.5) \\
121(23.0)\end{array}$ & $\begin{array}{c}68(18.8) \\
1(2.2) \\
49(40.5)\end{array}$ & 16.067 & 0.000 \\
\hline HABITS & $\begin{array}{l}\text { Smoking } \\
\text { Alcohol } \\
\text { Added salt }\end{array}$ & $\begin{array}{ll}212 & (40.2) \\
216 & (40.9) \\
128 & (24.3)\end{array}$ & $\begin{array}{ll}61 & (28.8) \\
60 & (27.8) \\
29 & (22.6)\end{array}$ & $\begin{array}{l}8.31 \\
5.92 \\
.007\end{array}$ & $\begin{array}{l}0.004 \\
0.015 \\
.934\end{array}$ \\
\hline DIET & $\begin{array}{l}\text { Vegetarian } \\
\text { Non-vegetarian }\end{array}$ & $\begin{aligned} 46 & (8.7) \\
481 & (91.3)\end{aligned}$ & $\begin{array}{r}11(23.9) \\
107(22.2)\end{array}$ & 0.067 & 0.795 \\
\hline
\end{tabular}

Table 6. Multivariate relationship between significant variables and hypertension

\begin{tabular}{|c|c|c|c|}
\hline Variable & Category & Odd's Ratio ( $95 \%$ C I ) & $\mathrm{p}$-value \\
\hline GENDER & $\begin{array}{l}\text { Female } \\
\text { Male }\end{array}$ & $\begin{array}{l}\text { Reference } \\
0.43(0.26-0.69)\end{array}$ & $-\overline{0}$ \\
\hline AGE GROUP & $\begin{array}{l}18-29 \\
30-39 \\
40-49 \\
50-59 \\
\geq 60\end{array}$ & $\begin{array}{l}\text { Reference } \\
2.6(1.15-5.89) \\
1.19(0.63-2.27) \\
0.79(0.44-1.41) \\
11.21(3.99-31.49)\end{array}$ & $\begin{array}{l}- \\
0.02 \\
0.59 \\
0.42 \\
0.00\end{array}$ \\
\hline LITERACY & $\begin{array}{l}\text { Graduate } \\
10+2 \\
\text { Middle \& High School } \\
\text { Primary } \\
\text { Illiterate }\end{array}$ & $\begin{array}{l}\text { Reference } \\
(0.19-2.29) \\
(0.17-0.85) \\
0.79(0.37-1.69) \\
1.41(0.84-2.37)\end{array}$ & $\begin{array}{l}- \\
0.51 \\
0.20 \\
0.54 \\
0.19\end{array}$ \\
\hline $\begin{array}{l}\text { PHYSICAL } \\
\text { ACTIVITY }\end{array}$ & $\begin{array}{l}\text { Heavy } \\
\text { Moderate } \\
\text { Sedentary }\end{array}$ & $\begin{array}{l}\text { Reference } \\
2.44(1.50-3.95) \\
0.87(0.45-1.78)\end{array}$ & $\begin{array}{l}- \\
0.00 \\
0.71\end{array}$ \\
\hline BMI & $\begin{array}{l}\text { Normal } \\
\text { Underweight } \\
\text { Overweight }\end{array}$ & $\begin{array}{l}\text { Reference } \\
1.85(0.95-3.62) \\
(1.47-8.81)\end{array}$ & $\begin{array}{l}- \\
0.70 \\
0.00\end{array}$ \\
\hline SMOKING & $\begin{array}{l}\text { No } \\
\text { Yes }\end{array}$ & $\begin{array}{l}\text { Reference } \\
0.53(0.34-0.80)\end{array}$ & $\begin{array}{l}- \\
0.00\end{array}$ \\
\hline ALCOHOL & $\begin{array}{l}\text { No } \\
\text { Yes }\end{array}$ & $\begin{array}{l}\text { Reference } \\
0.65(0.42-0.99)\end{array}$ & $\begin{array}{l}- \\
0.04\end{array}$ \\
\hline
\end{tabular}




\section{Risk factors of hypertension}

Though bivariate analysis showed significant correlation between hypertension with gender, higher age, literacy, physical inactivity, body mass index, smoking and alcohol consumption, multivariate analysis using the logistic regression only excluded literacy as independent risk factor whereas gender, higher age, physical inactivity, body mass index, smoking and alcohol consumption remained to have significant influence on prevalence of hypertension.

Prevalence of hypertension is age related. In our study prevalence of hypertension has shown consistent increase with age so has several other studies. Sharma D et.al ${ }^{12}$ in their study in suburban area of Nepal found that the prevalence of hypertension increased with age. Das SK et.al ${ }^{15}$ in their study found significant association of hypertension with age. Sharma AK et.al in their study found age to be the significant predictor of hypertension. ${ }^{16}$ Shah SMA et.al.in their study among adults of Pakistan found age to be independently associated with higher prevalence of hypertension. ${ }^{17}$ Cappuccino FP et.al in their study in African population found the prevalence of hypertension increased with age. ${ }^{18}$

Current study can be compared to other study from Nepal. Vaidya A et.al in their study showed age, physical inactivity and obesity as independent risk factors of hypertension which keep up with our study but unlike our study where positive correlation between smoking, alcohol consumption and high blood pressure has been reported their study does not show significant association between use of tobacco and alcohol with hypertension. ${ }^{14}$ Like present findings Kumar P et.al in their study found that smoking and alcohol consumption are independent and significant risk factors of hypertension. ${ }^{19}$ Shanthirani CS et.al came up with the conclusion that although smoking has positive association with high blood pressure but alcohol consumption did not show significant association with hypertension. ${ }^{20}$

These results contrasts with those from study by Thankappan KR et.al and Wang W et.al. ${ }^{21-22}$ In their study they found that smoking has inverse association with prevalence of hypertension. Wang $W$ et.al in their study found that subjects with a history of current alcohol consumption had higher risk of hypertension than those who do not. ${ }^{22}$ Criqui $\mathrm{MH}$ et.al in their study in North American populations found that blood pressure to be positively and significantly $(p<0.05)$ related to alcohol consumption. ${ }^{23}$ Hazarika NC et.al in their study found that consumption of locally prepared alcohol is independent determinant of hypertension. ${ }^{24}$

As could be anticipated, physical inactivity and BMI were associated with higher levels of blood pressure. Several studies have shown the significant association between hypertension and BMI. ${ }^{14-17,20,21}$ Wasir HS et.al, Singh RB et.al and several other studies have found that lower physical activity was positively associated with hypertension and thus present study findings are comparable to them. ${ }^{15,16,20,25,26}$

\section{CONCLUSION}

Hypertension is on rise in Nepal and must be regarded as a major public health issue. Our study has shown a high prevalence, even in rural area. About 30\% of study population had never ever had their blood pressure examined and about $40 \%$ of the hypertensives were not aware of their status which is worrisome. About $48 \%$ of the study population falls under the pre-hypertension category. Without proper knowledge and intervention programmes they are at risk of developing hypertension and its complications. The need of the hour is to increase awareness regarding modifiable risk factors of hypertension among the people and our study provides a background for a population-based intervention in attempts to prevent the rising problems of hypertension in the country.

\section{REFERENCES}

1. World Health report. Geneva, WHO,1997.

2. Keamey $\mathbf{P} M$, Whelton $M$, Reynolds $K$, Muntner $P$, Whelton $P, \mathrm{He}$ J. Global burden of hypertension: analysis of worldwide data. Lancet 2005; 365: 217-23

3. Nissien A, Bothig $\mathrm{S}$, Grenroth $\mathrm{H}$, Lopez AD. Hypertension in developing countries. World Health Stat Q 1988; 41: 141-154.

4. Reddy KS. Hypertension control in developing countries: generic issues. J. Hum Hypertension. 1996; 10: 33-38.

5. Seventh Report of the Joint National Committee on Prevention, Detection, Evaluation, and Treatment of High Blood Pressure. Hypertension 2003; 42: 1206.

6. World Health Organization. The World Health Report 2002: Reducing Risks, Promoting Healthy Life. Geneva, WHO; 2002.

7. Fuentes R, Ilmaniemi $\mathrm{N}$, Laurikainen $\mathrm{E}$, Tuomilehto J, Nissinen A. Hypertension in developing economies: a review of population-based studies carried out from 1980 to 1998. J Hypertens 2000; 18: 521-529.

8. Pandey MR. Hypertension in Nepal. Biblthea Cardio 1987; 42: 68-76.

9. Pandey MR, Dhungel S. Prevalence of hypertension in an urban community of Nepal. Journal of Nepal Medical Association. 1983; 21: 1-5.

10. Gupta R. Meta-analysis of prevalence of hypertension in India. Indian Heart Journal. 1997; 49: 43-48.

11. Gupta R. Trends in hypertension epidemiology in India. J Hum Hypertens 2004; 18: 73-78.

12. Sharma D, Man BKC, Rajbhandari S, Raut R, Baidya SG et.al. study of Prevalence, Awareness and Control of Hypertension in a Suburban Area of Kathmandu, Nepal. Indian Heart J 2006; 58: 34-37

13. Rawat B, Malla S, Vaidya A, Pandey R, Sodhi HS, Karki DB. Coronary risk factors in apparently healthy individuals. Postgraduate Medical Journal of Nepal 2001; 2:56-58.

14. Vaidya A, Pokharel PK, Karki P, Nagesh S. Exploring the iceberg of hypertension: A community based study in an eastern Nepal town. Kathmandu University Medical Journal (2007), Vol. 5, No. 3, Issue 19, 349-359

15. Das SK, Sanyal K, Basu A. Study of urban community survey in India: growing trend of high prevalence of hypertension in a developing 
country. Int J Med Sci. 2005; 2(2): 70-78

16. Sharma AK, Bhardwaj S, Chaturvedi S. Predictors of Hypertension in an Urban Indian Population. Indian Heart J 2006; 58: 21-27

17. Shah SMA, Luby S, Rahbar M, Khan AW, McCormick JB. Hypertension and its determinants among adults in high mountain villages of the Northern Areas of Pakistan. Journal of Human Hypertension (2001) $15,107-112$

18. Cappuccio FP, Micah FB, Emmett L, Kerry SM, Antwi S et.al. prevalence, Detection, Management and Control of Hypertension in Ashanti, West Africa. Hypertension. 2004;43:1017

19. Kumar P, Desai VK, Kosambia JK. Prevalence of Hypertension Amongst the Employees of a Mega-Industry of South Gujurat. Indian Journal of Community Medicine.Vol. 27, No. 1 (2002-01 - 2002-03)

20. Shanthirani CS, Pradeepa R, Deepa R, Premlatha G, Saroja R et.al. Prevalence and Risk Factors of Hypertension in a Selected South Indian Population - The Chennai Urban Population Study. JAPI. Vol. 51. Jan 2003.
21. Thankappan KR, Sivasankaran S, Abdulkhader S, Padmanabhan PG, Sharma PS, Mini GK, Vasan RS. Prevalence, Correlates, Awareness, Treatment and Control of Hypertension in Kumarakom, Kerela: Baseline Results of a Community-Based Intervention Program. Indian Heart J 2006; 58: 28-33.

22. Wang W, Lee ET, Fabsitz RR, Devereux R, Best L et.al. A Longitudinal Study of Hypertension Risk Factors and Their Relation to Cardiovascular Disease: The Strong Heart Study. Hypertension. 2006;47: 403-409.

23. Criqui MH, Wallace RB, Mishkel M, Barrett-Connor E, Heiss G. Alcohol consumption and blood pressure. The lipid research clinics prevalence study. Hypertension. 1981 Sep-Oct; 3(5): 557-65.

24. Hazarika NC, Biswas D, Narain K, Kalita HC, Mahanta J. Hypertension and its risk factors in tea garden workers of Assam. Natl Med J India. 2002 Mar-Apr;15(2):63-8.

25. Wasir HS, Ramachandran P, Nath LM. Prevalence of Hypertension in a Closed Urban Community. Indian Heart J Vol.36: No.4;1984

26. Singh RB, Beegom R, Ghosh S, Niaz MA, Rastogi V et.al. Epidemiological study of hypertension and its determinants in an urban population of North India. J Hum Hypertens. 1997 Oct;11(10):679-85. 